\title{
Redesain Metode Kerja Guna Reduksi Workload Fisik Dan Mental Pekerja Di Pt. Spu Palembang
}

\author{
Heri Setiawan', Ch. Desi Kusmindari ${ }^{2 *}$
}

\author{
1Program Studi Teknik Industri, Universitas Katolik Musi Charitasv \\ 2Program Studi Teknik Industri, Universitas Bina Darma, \\ Email: 1heri_setiawan@ukmc.ac.id,2desi_christofora@binadarma.ac.id
}

\begin{abstract}
PT. SPU Palembang is an industrial company that produces Hospital Furniture and Rehabilitation products with the trademark SHIMA. This study aims to reduce the physical and mental workload received by workers in the Machine Shop Department. This research is focused on the production process. Measurement of physical workload uses the calculation of the worker's heart rate by calculating the percentage of Cardiovascular Load (CVL). Measurement of mental workload using the National Aeronautics and Space Administration Task Load Index (NASA-TLX) score calculation method. The results obtained based on the aspect of NASA-TLX before the proposal almost all workers receive a mental workload with a value of $>80$ that is included in the category of heavy mental workloads except Milling-Drilling Workers (4) have a score $<80$ in the category of moderate mental workload. After the proposal all workers have a score $<80$ so that the mental workload received falls into the medium category. Based on the proposals applied to the Lathe Worker (1) and the Milling-Drilling Worker (4) namely the improvement of work methods in the process of turning, punching, and the proposed holding of a reminder as a tool to remember, the results obtained \%CVL from both workers $<30 \%$. Three other workers, although experiencing a decline, remained at $>30 \%$. The category of mental workload received by workers from previously included in the category of heavy mental workload dropped to moderate.
\end{abstract}

Keywords: Physical Workload, Mental Workload, NASA-TLX, \% CVL.

\section{LATAR BELAKANG}

PT. SPU merupakan perusahaan yang bergerak di bidang industri alat bantu kesehatan, seperti; kursi roda, tongkat, tongkat ketiak dan walkers. Perusahaan ini memproduksi kurang lebih 19.000 alat bantu kesehatan setiap bulannya. Perusahaan ini terletak di Lorong Sebatok Jl. Taman Kenten No. 76A, Duku, Kec. Ilir Timur II, Kota Palembang, Sumatera Selatan 30163. PT. SPU terbagi atas 8 departemen, yaitu; 1) Departemen bahan baku dan sparepart, 2) Departemen preparasi, 3) Departemen machine shop, 4) Departemen welding furniture dan rehap, 5) departemen finishing, 6) Departemen gudang / logistik, 7) Departmen assembly, dan 8) Departemen barang jadi dan pemasaran. Proses produksi alat bantu kesehatan di PT SPU secara umum dilakukan oleh seluruh departemen produksi yang melibatkan pekerja yang bekerja Departemen Macbine Shop. Permasalahan utama yang akan diangkat adalah terkait dengan fokus pekerja yang menurun selama jam kerja berlangsung.

Pekerja di Departemen Macbine Shop menambahkan informasi bahwa penurunan fokus kerja disebabkan karena pekerjaan di bagian proses Departemen macbine shop didominasi dengan sikap kerja berdiri, mengangkat material spare part kurang lebih seberat $45 \mathrm{~kg}$, menurunkan material spare part dan membungkuk saat bekerja sehingga dapat menimbulkan kelelahan yang dapat membuat timbulnya kesalahan-kesalahan saat bekerja. Selain beban kerja fisik, penyebab fokus pekerja menurun adalah dikarenakan adanya proses mengingat-ingat saat yang tepat mengangkat material setelah proses cutting, proses bubut, scrab, punch dan milling-drilling sehingga pekerja harus tetap waspada dalam bekerja. Penelitian ini menganalisis beban kerja fisik, beban kerja mental pekerja untuk dilakukan perbaikan/ redesain metode kerja agar dapat mengurangi/ mereduksi workload yang diterima oleh pekerja Departemen Machine Shop. Dampak turunnya fokus pekerja adalah adanya defect pada material spare part yang dirakit. Menurut informasi dari kepala produksi, rata-rata produk defect yang dihasilkan adalah kurang lebih $2 \%$ setiap harinya. Departemen Machine Shop terdiri dari 5 aktivitas pekerjaan yaitu, aktivitas bubut, scrab, punch, milling-driling, dan potong (cutting). Kepresisian dan konsentrasi pekerja pada saat melakukan proses scrab dalam pembentukan/penghalusan permukaan, proses punch mengolah bahan potongan menjadi bahan sesuai dengan cetakan/dies, dan pada proses milling-drilling proses melubangi sesuai dengan mata bor/ milling yang digunakan pada mesin. Berdasarkan latar belakang diatas maka rumusan masalah dari penelitian ini adalah; 
bagaimana workload fisik dan mental yang diterima oleh pekerja? dan bagaimana usulan perbaikan metode kerja untuk mereduksi workload fisik dan mental yang diterima oleh pekerja?.

\section{METODOLOGI PENELITIAN}

Penelitian yang dilakukan di industri karet crumb rubber di Provinsi Sumsel [12],[13] menjelaskan bahwa perancangan ulang stasiun kerja berbasiskan pada Ergonomi Total (Pendekatan SHIP dan Teknologi Tepat Guna) dan integrasi Ergo-Mikro dan Makro berdampak pada redesain pekerjaan, alat-alat kerja, organisasi kerja dan lingkungan kerja berdampak menurunkan beban kerja fisik dan mental. Sedangkan penelitian pada UKM unggulan di Provinsi Sumsel menghasilkan lingkungan kerja yang lebih ergonomis: ENASE (Efektif, Nayaman, Aman, Sehat, Efisien) yang pada akhirnya dapat menurunkan keluhan musculoskeletal dan kelelahan serta meningkatkan produktivitas kerja pekerja[16]. Penelitian di sebuah perusahaan yang bergerak dibidang perkayuan, meliputi kayu lapis, wood working, dan particle board. Metode yang digunakan dalam penelitian ini yaitu, metode pengukuran beban kerja mental National Aeronautics and Space Administration Task Load Index (NASA TLX) dan metode pengukuran beban kerja fisik yaitu menggunakan aspek work sampling. Menurut perhitungan beban kerja fisik dan mental, pekerja yang memiliki load terendah adalah terdapat pada pekerjaan Quality Control Produk sebanyak 72,3\%, sedangkan untuk skor paling tinggi diterima oleh bagian pekerjaan Quality Control Finish Board dengan nilai 108,1\% [9]. Penelitian mengenai analisis perbaikan kondisi lingkungan kerja terhadap beban kerja mental dilakukan pada perusahaan yang bergerak di bidang manufaktur, dengan produk utama yang dipasarkan adalah rokok [10]. Tujuan dari penelitian ini adalah untuk melakukan 5 perbaikan kondisi lingkungan kerja di bagian pencampuran tembakau. Penelitian ini melakukan pengukuran beban kerja mental dengan menggunakan metode Subjective Workload Assesment Technique (SWAT) untuk mengetahui pengaruh perbaikan kondisi lingkungan kerja tersebut. Hasil dari penelitian ini adalah perbaikan kondisi lingkungan kerja dengan menambahkan blower dan penggunaan penutup telinga dan didapatkan kondisi lingkungan kerja yang sesuai dengan standar. Selain itu, setelah dilakukan perbaikan kondisi lingkungan kerja menjadi termasuk dalam kondisi ringan.

Ergonomi merupakan suatu ilmu, seni dan penerapan teknologi yang digunakan untuk menyetarakan segala fasilitas yang digunakan baik dalam istirahat maupun saat sedang beraktivitas dengan segala keterbatasan dan kemampuan manusia, baik mental ataupun fisik sehingga kualitas hidup secara keseluruhan dapat menjadi lebih baik dan diperoleh produktivitas yang setinggi-tingginya [11]. Performansi atau kemampuan kerja seorang pekerja tergantung pada perbandingan antara besarnya tuntutan kerja dengan besarnya kemampuan pekerja tersebut, apabila: a) tuntutan tugas yang lebih besar dari kemampuan atau kapasitas pekerja, maka dapat menyebabkan overstress, kelelahan, kecelakaan kerja, cidera, rasa sakit, penyakit, dan lain-lain, b) tuntutan tugas yang lebih rendah dari kemampuan pekerja, maka dapat menyebabkan understress, kebosanan, kejenuhan, dan lain-lain, dan c) tuntutan tugas seimbang dengan kemampuan pekerja, maka akan tercapai kondisi kerja yang nyaman, aman, dan produktif.

Beban kerja timbul dikarenakan adanya interaksi antara pekerja dengan tugas yang diterima. Pengukuran beban kerja sangat diperlukan oleh suatu perusahaan guna mengakomodasi faktor psikologis manusia dalam bekerja, sehingga tidak terjadi hal-hal yang parah dan dapat menimbulkan penurunan motivasi kerja. Secara umum hubungan beban kerja dengan kapasitas kerja dipengaruhi oleh berbagai faktor yang begitu kompleks, baik dari segi faktor eksternal maupun faktor internal. Pada dasarnya beban kerja dibedakan menjadi dua, yaitu: a) beban kerja fisik menyebutkan bahwa untuk penilaian beban kerja fisik dapat dilakukan dengan metode secara obyektif melalui metode penilaian langsung dan tidak langsung [1],[2],[8],[11]. Metode pengukuran beban kerja fisik secara langsung adalah 9 pengukuran yang dilakukan dengan pengukuran energi yang dikeluarkan melalui asupan oksigen selama bekeja. Semakin berat beban kerja maka semakin banyak energi yang dikonsumsi atau diperlukan. Meskipun metode dengan menggunakan asupan oksigen lebih akurat, namun metode tersebut hanya dapat mengukur dengan waktu kerja yang cukup singkat dan diperlukan peralatan yang mahal, sedangkan metode pengukuran tidak langsung dapat dilakukan dengan menghitung denyut nadi pekerja selama melakukan pekerjaan. Satu pendekatan untuk mengetahui berat atau ringannya beban kerja adalah dengan cara menghitung konsumsi oksigen, nadi kerja, suhu inti tubuh dan kapasitas ventilasi paru [3],[4],[15]. Ketegori berat dan ringannya beban kerja didasarkan pada metabolisme, suhu tubuh dan denyut jantung dapat dilihat pada Tabel 2.1. 
Jurnal TEKNO

(Civil Engineeering, Elektrical Engineeering and Industrial Engineering)

Vol. 17, No : 2, Oktober 2020 , p-ISSN:1907-5243, e-ISSN: 2655-8416

Tabel 2.1. Kategori Beban Kerja berdasarkan Metabolisme, Respirasi, Suhu Tubuh dan Denyut Jantung

\begin{tabular}{ccccc}
\hline $\begin{array}{c}\text { Kategori Beban } \\
\text { Kerja }\end{array}$ & $\begin{array}{c}\text { Konsumsi } \\
\text { Oksigen } \\
(\mathbf{l} / \mathbf{m i n})\end{array}$ & $\begin{array}{c}\text { Ventilasi Paru } \\
\mathbf{( 1 / \text { min) }}\end{array}$ & $\begin{array}{c}\text { Suhu } \\
\text { Rektal (C) }\end{array}$ & $\begin{array}{c}\text { Denyut jantung } \\
\text { (denyut/min) }\end{array}$ \\
\hline Ringan & $0,5-1,0$ & $11-20$ & 37,5 & $75-100$ \\
Sedang & $1,0-1,5$ & $20-31$ & $37,5-38,0$ & $100-125$ \\
Berat & $1,5-2,0$ & $32-43$ & $38,0-38,5$ & $125-150$ \\
Sangat Berat & $2,0-2,5$ & $43-56$ & $38,5-39,0$ & $150-175$ \\
Sangat Berat Sekali & $2,5-4,0$ & $60-100$ & $>39$ & $>175$ \\
\hline
\end{tabular}

(Sumber: Christensen. 1991:1699)

Berat dan ringannya suatu beban kerja yang diterima oleh pekerja dapat digunakan sebagai evaluasi untuk menentukan seberapa lama seorang pekerja dapat melakukan aktivitas/ kegiatan pekerjaannya, disesuaikan dengan kemampuan atau kapasitas kerja. Hal tersebut akan memberikan dampak di mana semakin berat beban kerja yang diterima, maka akan semakin pendek waktu kerja seseorang untuk berkerja tanpa kelelahan dan gangguan fisiologis yang berarti begitupun sebaliknya. Metode-metode dan peralatan untuk mengukur beban kerja fisik adalah sebagai berikut: 1) Pengukuran konsumsi energi, 2) Pengukuran konsumsi oksigen, dan 3) Pengukuran denyut jantung. Denyut nadi untuk mengestimasi indek beban kerja fisik terdiri dari beberapa jenis yang didefinisikan oleh Grandjean (2000), yaitu: a) Denyut nadi istirahat, yaitu rerata denyut nadi sebelum pekerjaan dimulai, b) Denyut nadi kerja, yaitu rerata denyut nadi selama bekerja, c) Nadi kerja, yaitu selisih antara denyut nadi istirahat dan denyut nadi kerja. Klasifikasi beban kerja berdasarkan peningkatan denyut nadi kerja yang dibandingkan dengan denyut nadi maksimumnya [7],[14]. Beban kerja kardiovaskuler (cardiovascular load $=\% \mathrm{CVL}$ ) dapat dihitung dengan rumus sebagai berikut:

Keterangan:

$$
\% \mathrm{CVL}=\frac{100 \mathrm{x}(\text { denyut nadi kerja }- \text { denyut nadi istirahat })}{\text { denyut nadi maksimum }- \text { denyut nadi istirahat }}
$$

Denyut nadi istirahat

Denyut nadi kerja

Denyut nadi maksimum

Klasifikasi \%CVL

$$
\begin{aligned}
& =\text { Rerata denyut nadi sebelum pekerjaan dimulai } \\
& =\text { Rerata denyut nadi selama bekerja } \\
& =(220-\text { umur }) \text { untuk laki-laki dan }(200-\text { umur }) \text { untuk wanita } \\
& =\text { a) }<30 \%=\text { Tidak terjadi kelelahan, b) } 30 \% \text { s.d. }<60 \%=\text { Diperlukan } \\
& \text { perbaikan, c) } 60 \% \text { s.d. }<80 \%=\text { Kerja dalam waktu singkat, d) } 80 \% \text { s.d. }< \\
& 100 \%=\text { Diperlukan tindakan segera, dan e) }>100 \%=\text { Tidak diperbolehkan } \\
& \text { beraktivitas. }
\end{aligned}
$$

Salah satu pengukuruan beban kerja secara subjektif adalah NASA-TLX. Model ini dikembangkan oleh badan penerbangan dan ruang angkasa Amerika Serikat. (NASA Ames Research Center). NASA - Task Load Index adalah prosedur rating multi dimensional, yang membagi workload atas dasar rata - rata pembebanan enam subskala. NASA-TLX memiliki beberapa kelebihan diantaranya adalah: a) Lebih sensitif terhadap berbagai kondisi pekerjaan, b) Setiap faktor penilaian mampu memberikan sumbangan informasi mengenai struktur tugas, c) Proses penentuan keputusan lebih cepat dan sederhana, d) Lebih praktis diterapkan dalam lingkungan operasional, dan e) Analisis data lebih mudah diselesaikan dibanding dengan SWAT yang memerlukan program conjoint analisis. Langkah langkah yang dilakukan dalam pengukuran beban kerja mental dengan menggunakan metode NASA-TLX adalah sebagai berikut: a) Penjelasan indikator beban kerja mental yang akan digunakan sebagai tolak ukur dapat dilihat pada Tabel 2.2.

\section{Tabel 2.2. $\quad$ Skala, Rating, dan Keterangan pada NASA-TLX}

\begin{tabular}{lcl}
\hline \multicolumn{1}{c}{ Skala } & \multicolumn{1}{c}{ Rating } & \multicolumn{1}{c}{ Keterangan } \\
\hline $\begin{array}{l}\text { Kebutuhan } \\
\text { Mental }(\mathrm{KM})\end{array}$ & Rendah, Tinggi & $\begin{array}{l}\text { Seberapa besar aktivitas/kegiatan mental dan perseptual yang } \\
\text { dibutuhkan untuk melihat, mengingat dan mencari. Apakah pekerjaan } \\
\text { tersebut mudah atau sulit, sederhana atau kompleks, longgar atau ketat. }\end{array}$ \\
$\begin{array}{l}\text { Kebutuhan Fisik } \\
\text { (KF) }\end{array}$ & Rendah, Tinggi & $\begin{array}{l}\text { Jumlah aktivitas/ kegiatan fisik yang dibutuhkan (misalnya: mendorong, } \\
\text { menarik, mengontrol putaran, dan lain-lain). }\end{array}$
\end{tabular}




\begin{tabular}{lll}
\hline \multicolumn{1}{c}{ Skala } & \multicolumn{1}{c}{ Rating } & \multicolumn{1}{c}{ Keterangan } \\
\hline $\begin{array}{l}\text { Kebutuhan } \\
\text { Waktu (KW) }\end{array}$ & Rendah, Tinggi & $\begin{array}{l}\text { Jumlah tekanan yang berkaitan dengan waktu yang dirasakan selama } \\
\text { elemen pekerjaan berlangsung. Apakah pekerjaan perlahan atau santai } \\
\text { atau cepat dan melelahkan. }\end{array}$ \\
Performance (P) & $\begin{array}{l}\text { Tidak tepat, } \\
\text { Seberapa besar keberhasilan seseorang di dalam pekerjaannya dan } \\
\text { seberapa puas dengan hasil kerjanya. }\end{array}$ \\
$\begin{array}{l}\text { Tingkat Usaha } \\
\text { (TU) }\end{array}$ & Rendah, Tinggi & $\begin{array}{l}\text { Seberapa keras kerja mental dan fisik yang dibutuhkan untuk } \\
\text { menyelesaikan pekerjaan. }\end{array}$ \\
Tingkat Frustasi & Rendah, Tinggi & $\begin{array}{l}\text { Seberapa tidak aman, putus asa, tersinggung, terganggu, dibandingkan } \\
\text { dengan perasaan aman, puas, nyaman dan kepuasan diri yang dirasakan. }\end{array}$ \\
\hline
\end{tabular}
(Sumber: [5])

b) Pembobotan; responden memilih salah satu dari dua indikator yang dirasakan lebih dominan menimbulkan workload mental terhadap pekerjaan tersebut. Kuisioner NASA-TLX yang diberikan berbentuk perbandingan berpasangan. Kuisioner yang telah terkumpul kemudian dihitung jumlah tally dari setiap indikator yang dirasakan paling berpengaruh. Jumlah tally ini kemudian akan menjadi bobot untuk tiap indikator beban mental, c) Pemberian Rating; responden diminta memberi rating terhadap keenam indikator beban mental. Rating yang diberikan adalah beban subyektif tergantung pada workload mental yang dirasakan oleh responden tersebut. Untuk mendapatkan skor beban mental NASA-TLX, bobot dan rating untuk setiap indikator dikalikan kemudian dijumlahkan dan dibagi 15 (jumlah perbandingan berpasangan), d) Interpretasi Hasil Nilai Skor. Berdasarkan penjelasan [6] dalam teori NASA TLX, skor beban kerja yang diperoleh dapat diintepretasikan sebagai berikut: i) Nilai skor $>80$ menyatakan beban pekerjaan berat, ii) Nilai skor 50-70 menyatakan beban pekerjaan sedang, iii) Nilai skor $<50$ menyatakan beban pekerjaan agak ringan

Fault Tree Analysis (FTA) awalnya dikembangkan pada tahun 1962 di Laboratorium Bell oleh HA Watson, di bawah US Fair Force Divisi Balistik Sistem yang berkaitan dengan studi tentang evaluasi keselamatan sistem peluncuran minuteman misle antar benua. Kegunaan FTA adalah untuk melihat reabilitas dari suatu produk dan menunjukan hubungan sebab akibat diantara suatu kejadian dengan kejadian lain. Dalam membangun model FTA dilakukan dengan mewawancarai pihak pekerja di lantai produksi dan melakukan pengamatan langsung terhadap proses produksi. Dalam penelitian ini menggunakan FTA model logis dan grafis yang mewakili berbagai kombinas dari peristiwa yang tidak diinginkan. FTA menggunakan diagram pohon untuk menunjukan cause-andeffect dari peristiwa.

Studi lapangan dengan melihat kondisi yang terjadi di perusahaan untuk mengevaluasi perlunya dilakukan perbaikan metode kerja untuk mengurangi beban kerja mental dan fisik pada pekerja di Departemen Machine Shop. Permasalahan ditinjau dari studi lapangan yang telah diamati, menentukan obyek penelitian yang akan diteliti beban kerja fisik dan beban mentalnya, yaitu pekerja di Departemen Machine Shop.

Metode pengumpulan data yang digunakan dalam penelitian ini adalah sebagai berikut: a) wawancara ke responden pekerja kepala bagian produksi. Hal ini dilakukan untuk mendapatkan informasi mengenai keluhan apa yang dialami pekerja di Departemen Machine Shop saat bekerja dan permasalahan apa yang ditimbulkan akibat keluhan tersebut, b) pengukuran denyut jantung pekerja di Departemen Machine Shop guna mengetahui beban kerja fisik yang diterima. Pengukuran denyut jantung dilakukan dengan cara menghitung jumlah denyut nadi sebelum bekerja dan jumlah denyut nadi saat bekerja. Dalam pengambilan data untuk menyetarakan kondisi waktu sebelum kerja dengan jam istirahat dilakukan dengan cara pekerja tidak langsung diukur denyut nadinya, melainkan diistirahatkan 5 menit dahulu sebelum dilakukan pengukuran. Alat yang digunakan untuk memperoleh data denyut jantung adalah pulsemeter digital. Frekuensi pengambilan data dilakukan selama 5 hari kerja dalam seminggu, satu hari pengambilan data dibagi menjadi 4 waktu yaitu jam sebelum bekerja sebelum jam 7.30. Pengambilan data kedua saat jam kerja yaitu sebelum jam 12.00. Pengambilan data ketiga saat jam istirahat yaitu antara jam 12.00 sampai jam 13.00. Pengambilan data keempat saat bekerja setelah jam istirahat yaitu pukul 13.00 s.d. 16.00, c) Kuesioner NASA-TLX; pengumpulan data koesioner dengan beberapa pertanyaan dan diisikan oleh pekerja.

Analisis beban kerja fisik dilakukan dengan menghitung \%CVL dan selanjutnya mengategorikan tingkat beban kerja fisik yang diterima oleh pekerja di Departemen Machine Shop sesuai dengan klasifikasi yang sudah ditentukan. Untuk beban kerja mental dilakukan analisis tingkat beban kerja mental menggunakan perbandingan berpasangan setelah itu melakukan perhitungan pembobotan dan pemberian 
rating sehingga dapat menentukan tingkat beban kerja mental yang diterima oleh pekerja di Departemen Machine Shop.

Analisis penyebab masalah dilakukan untuk mengidentifikasi apa saja faktor yang menyebabkan permasalahan terjadi, sehingga dapat menentukan usulan implementasi (after) apa yang dapat dilakukan untuk mengurangi faktor penyebab permasalahan. Dalam penelitian ini yang menjadi permasalahan utama adalah turunnya tingkat fokus pekerja dalam bekerja. Instrumen yang digunakan untuk analisis penyebab masalah dalam penelitian ini adalah Fault Tree Analisis. Pemberian usulan implementasi (after) diberikan jika pekerja di Departemen Machine Shop mengalami kelelahan berdasarkan pengolahan data denyut jantung dan data kuesioner. Pemberian usulan ini diharapkan agar beban kerja fisik dan mental yang dialami pekerja dapat berkurang. Pemberian usulan untuk pekerja di Departemen Machine Shop yang mengalami beban kerja yang berlebih diantaranya adalah perbaikan metode kerja dengan cara mengubah cara kerja kemudian penarikan kesimpulan. Saran perbaikan kerja bila terdapat kondisi kerja yang belum sesuai dan penelitian lanjutan yang dapat dilaksanakan untuk perbaikan perusahaan.

\section{HASIL DAN PEMBAHASAN}

Data denyut jantung yang diperoleh dari kelima pekerja di Departemen Machine Shop dapat dilihat pada Tabel 3.1.

Tabel 3.1. Data Denyut Jantung Pekerja Bubut (1)

\begin{tabular}{|c|c|c|c|c|c|c|c|c|}
\hline $\begin{array}{l}\text { Tanggal } \\
\text { Nama } \\
\text { Umur }\end{array}$ & $\begin{array}{l}: 1-5 \text { Juli } 20 \\
: \text { Pekerja Bu } \\
: 35 \text { tahun }\end{array}$ & & & & & & & \\
\hline Hari ke- & $\begin{array}{c}\text { Waktu } \\
\text { Pengam- } \\
\text { bilan Data }\end{array}$ & $\begin{array}{c}\text { Denyut } \\
\text { Jantung } \\
\text { Sebelum } \\
\text { Kerja } \\
\text { (Denyut/ } \\
\text { menit) }\end{array}$ & $\begin{array}{c}\text { Waktu } \\
\text { Pengam- } \\
\text { bilan Data }\end{array}$ & $\begin{array}{c}\text { Denyut } \\
\text { Jantung } \\
\text { Selama } \\
\text { Kerja } \\
\text { (Denyut / } \\
\text { menit) }\end{array}$ & $\begin{array}{c}\text { Waktu } \\
\text { Pengam- } \\
\text { bilan Data }\end{array}$ & $\begin{array}{l}\text { Denyut } \\
\text { Jantung } \\
\text { Sebelum } \\
\text { Kerja } \\
\text { (Denyut/ } \\
\text { menit) }\end{array}$ & $\begin{array}{l}\text { Waktu } \\
\text { Pengam- } \\
\text { bilan } \\
\text { Data }\end{array}$ & $\begin{array}{c}\text { Denyut } \\
\text { Jantung } \\
\text { Selama } \\
\text { Kerja } \\
\text { (Denyut/ } \\
\text { menit) }\end{array}$ \\
\hline 1 & 07.11 & 64 & 11.00 & 105 & 12.20 & 73 & 15.00 & 120 \\
\hline 2 & 07.13 & 71 & 11.30 & 108 & 12.30 & 75 & 15.25 & 115 \\
\hline 3 & 07.25 & 69 & 11.25 & 116 & 12.25 & 70 & 15.00 & 110 \\
\hline 4 & 07.16 & 68 & 11.15 & 105 & 12.40 & 75 & 15.15 & 113 \\
\hline 5 & 07.21 & 69 & 11.20 & 114 & 12.45 & 74 & 15.05 & 115 \\
\hline
\end{tabular}

Tabel 3.2. Data Denyut Jantung Pekerja Scrab (2)

\begin{tabular}{|c|c|c|c|c|c|c|c|c|}
\hline $\begin{array}{l}\text { Tanggal } \\
\text { Nama } \\
\text { Umur }\end{array}$ & $\begin{array}{l}: 1-5 \text { Juli } 20 \\
: \text { Pekerja } S c \\
: 32 \text { tahun }\end{array}$ & & & & & & & \\
\hline Hari ke- & $\begin{array}{c}\text { Waktu } \\
\text { Pengam- } \\
\text { bilan Data }\end{array}$ & $\begin{array}{l}\text { Denyut } \\
\text { Jantung } \\
\text { Sebelum } \\
\text { Kerja } \\
\text { (Denyut/ } \\
\text { menit) }\end{array}$ & $\begin{array}{c}\text { Waktu } \\
\text { Pengam- } \\
\text { bilan Data }\end{array}$ & $\begin{array}{c}\text { Denyut } \\
\text { Jantung } \\
\text { Selama } \\
\text { Kerja } \\
\text { (Denyut/ } \\
\text { menit) }\end{array}$ & $\begin{array}{c}\text { Waktu } \\
\text { Pengam- } \\
\text { bilan Data }\end{array}$ & $\begin{array}{l}\text { Denyut } \\
\text { Jantung } \\
\text { Sebelum } \\
\text { Kerja } \\
\text { (Denyut/ } \\
\text { menit) }\end{array}$ & $\begin{array}{l}\text { Waktu } \\
\text { Pengam- } \\
\text { bilan } \\
\text { Data }\end{array}$ & $\begin{array}{c}\text { Denyut } \\
\text { Jantung } \\
\text { Selama } \\
\text { Kerja } \\
\text { (Denyut/ } \\
\text { menit) }\end{array}$ \\
\hline 1 & 07.13 & 75 & 11.05 & 122 & 12.35 & 77 & 15.05 & 118 \\
\hline 2 & 07.15 & 72 & 11.25 & 125 & 12.25 & 78 & 15.15 & 122 \\
\hline 3 & 07.20 & 79 & 11.05 & 117 & 12.45 & 74 & 15.20 & 125 \\
\hline 4 & 07.27 & 80 & 11.35 & 122 & 12.35 & 80 & 15.25 & 121 \\
\hline 5 & 07.13 & 75 & 11.15 & 121 & 12.25 & 75 & 15.10 & 118 \\
\hline
\end{tabular}


(Civil Engineeering, Elektrical Engineeering and Industrial Engineering)

Vol. 17, No : 2, Oktober 2020 , p-ISSN:1907-5243, e-ISSN: 2655-8416

Tabel 3.3. Data Denyut Jantung Pekerja Punch (3)

\begin{tabular}{|c|c|c|c|c|c|c|c|c|}
\hline $\begin{array}{l}\text { Tanggal } \\
\text { Nama } \\
\text { Umur }\end{array}$ & $\begin{array}{l}: 1-5 \text { Juli } 20 \\
: \text { Pekerja } P u \\
: 37 \text { tahun }\end{array}$ & & & & & & & \\
\hline Hari ke- & $\begin{array}{c}\text { Waktu } \\
\text { Pengam- } \\
\text { bilan Data }\end{array}$ & $\begin{array}{c}\text { Denyut } \\
\text { Jantung } \\
\text { Sebelum } \\
\text { Kerja } \\
\text { (Denyut/ } \\
\text { menit) }\end{array}$ & $\begin{array}{c}\text { Waktu } \\
\text { Pengam- } \\
\text { bilan Data }\end{array}$ & $\begin{array}{c}\text { Denyut } \\
\text { Jantung } \\
\text { Selama } \\
\text { Kerja } \\
\text { (Denyut/ } \\
\text { menit) }\end{array}$ & $\begin{array}{c}\text { Waktu } \\
\text { Pengam- } \\
\text { bilan Data }\end{array}$ & $\begin{array}{l}\text { Denyut } \\
\text { Jantung } \\
\text { Sebelum } \\
\text { Kerja } \\
\text { (Denyut/ } \\
\text { menit) }\end{array}$ & $\begin{array}{l}\text { Waktu } \\
\text { Pengam- } \\
\text { bilan } \\
\text { Data }\end{array}$ & $\begin{array}{c}\text { Denyut } \\
\text { Jantung } \\
\text { Selama } \\
\text { Kerja } \\
\text { (Denyut/ } \\
\text { menit) }\end{array}$ \\
\hline 1 & 07.20 & 74 & 11.20 & 112 & 12.45 & 78 & 15.10 & 116 \\
\hline 2 & 07.10 & 67 & 11.10 & 115 & 12.40 & 75 & 15.35 & 112 \\
\hline 3 & 07.15 & 70 & 11.15 & 107 & 12.25 & 76 & 15.40 & 115 \\
\hline 4 & 07.23 & 72 & 11.30 & 115 & 12.40 & 74 & 15.45 & 117 \\
\hline 5 & 07.15 & 72 & 11.10 & 112 & 12.50 & 70 & 15.15 & 116 \\
\hline
\end{tabular}

Tabel 3.4. Data Denyut Jantung Pekerja Milling-Drilling (4)

\begin{tabular}{|c|c|c|c|c|c|c|c|c|}
\hline $\begin{array}{l}\text { Tanggal } \\
\text { Nama } \\
\text { Umur }\end{array}$ & $\begin{array}{l}: 1-5 \text { Juli } 2 \\
: \text { Pekerja } M \\
: 26 \text { tahun }\end{array}$ & -Drilling ( & & & & & & \\
\hline Hari ke- & $\begin{array}{c}\text { Waktu } \\
\text { Pengam- } \\
\text { bilan Data }\end{array}$ & $\begin{array}{c}\text { Denyut } \\
\text { Jantung } \\
\text { Sebelum } \\
\text { Kerja } \\
\text { (Denyut/ } \\
\text { menit) }\end{array}$ & $\begin{array}{c}\text { Waktu } \\
\text { Pengam- } \\
\text { bilan Data }\end{array}$ & $\begin{array}{c}\text { Denyut } \\
\text { Jantung } \\
\text { Selama } \\
\text { Kerja } \\
\text { (Denyut/ } \\
\text { menit) }\end{array}$ & $\begin{array}{c}\text { Waktu } \\
\text { Pengam- } \\
\text { bilan Data }\end{array}$ & $\begin{array}{c}\text { Denyut } \\
\text { Jantung } \\
\text { Sebelum } \\
\text { Kerja } \\
\text { (Denyut/ } \\
\text { menit) }\end{array}$ & $\begin{array}{l}\text { Waktu } \\
\text { Pengam- } \\
\text { bilan } \\
\text { Data }\end{array}$ & $\begin{array}{c}\text { Denyut } \\
\text { Jantung } \\
\text { Selama } \\
\text { Kerja } \\
\text { (Denyut/ } \\
\text { menit) }\end{array}$ \\
\hline 1 & 07.15 & 69 & 11.25 & 112 & 12.15 & 73 & 15.20 & 110 \\
\hline 2 & 07.17 & 70 & 11.45 & 109 & 12.16 & 75 & 15.05 & 115 \\
\hline 3 & 07.25 & 75 & 11.35 & 113 & 12.10 & 69 & 15.25 & 105 \\
\hline 4 & 07.10 & 72 & 11.20 & 97 & 12.05 & 72 & 15.20 & 108 \\
\hline 5 & 07.12 & 73 & 11.05 & 110 & 12.35 & 70 & 15.35 & 117 \\
\hline
\end{tabular}

Tabel 3.5. Data Denyut Jantung Pekerja Potong (Cutting) (5)

\begin{tabular}{|c|c|c|c|c|c|c|c|c|}
\hline $\begin{array}{l}\text { Tanggal } \\
\text { Nama } \\
\text { Umur }\end{array}$ & $\begin{array}{l}: 1-5 \text { Juli } 2 \\
: \text { Pekerja Po } \\
: 28 \text { tahun }\end{array}$ & /Cutting & & & & & & \\
\hline Hari ke- & $\begin{array}{c}\text { Waktu } \\
\text { Pengam- } \\
\text { bilan Data }\end{array}$ & $\begin{array}{c}\text { Denyut } \\
\text { Jantung } \\
\text { Sebelum } \\
\text { Kerja } \\
\text { (Denyut/ } \\
\text { menit) }\end{array}$ & $\begin{array}{c}\text { Waktu } \\
\text { Pengam- } \\
\text { bilan Data }\end{array}$ & $\begin{array}{l}\text { Denyut } \\
\text { Jantung } \\
\text { Selama } \\
\text { Kerja } \\
\text { (Denyut/ } \\
\text { menit) }\end{array}$ & $\begin{array}{c}\text { Waktu } \\
\text { Pengam- } \\
\text { bilan Data }\end{array}$ & $\begin{array}{c}\text { Denyut } \\
\text { Jantung } \\
\text { Sebelum } \\
\text { Kerja } \\
\text { (Denyut/ } \\
\text { menit) }\end{array}$ & $\begin{array}{c}\text { Waktu } \\
\text { Pengam- } \\
\text { bilan } \\
\text { Data }\end{array}$ & $\begin{array}{c}\text { Denyut } \\
\text { Jantung } \\
\text { Selama } \\
\text { Kerja } \\
\text { (Denyut/ } \\
\text { menit) }\end{array}$ \\
\hline 1 & 07.23 & 66 & 11.20 & 111 & 12.30 & 76 & 15.35 & 118 \\
\hline 2 & 07.10 & 63 & 11.15 & 103 & 12.10 & 75 & 15.40 & 115 \\
\hline 3 & 07.29 & 65 & 11.30 & 119 & 12.30 & 69 & 15.15 & 125 \\
\hline 4 & 07.17 & 70 & 11.45 & 115 & 12.25 & 67 & 15.10 & 108 \\
\hline 5 & 07.15 & 68 & 11.25 & 118 & 12.55 & 70 & 15.25 & 120 \\
\hline
\end{tabular}

Perhitungan beban kerja mental pada seluruh pekerja di Departemen Machine Shop PT. SHU dapat dilihat pada Tabel 3.6.

Tabel 3.6. Data Kuesioner NASA-TLX Sebelum (Before) Implementasi

\begin{tabular}{cllccc}
\hline No. & \multicolumn{1}{c}{ Nama Pekerja } & \multicolumn{1}{c}{ Indikator } & Rating & Bobot & Rating x Bobot \\
\hline 1. & Pekerja Bubut (1) & Kebutuhan Mental & 90 & 3 & 270 \\
& & Kebutuhan Fisik & 90 & 4 & 360 \\
& Kebutuhan Waktu & 85 & 3 & 255 \\
& Performansi & 75 & 2 & 150 \\
& Usaha & 75 & 2 & 150 \\
& Frustasi & 55 & 1 & 55 \\
\cline { 2 - 5 } & Kebutuhan Mental & Total & 4 & $\mathbf{1 . 2 4 0}$ \\
\hline 2. & Pekerja Scrab (2) & Kebutuhan Fisik & 85 & 4 & 360 \\
& & Kebutuhan Waktu & 85 & 2 & 170 \\
& & Performansi & 75 & 2 & 150 \\
\hline
\end{tabular}


Jurnal TEKNO

(Civil Engineeering, Elektrical Engineeering and Industrial Engineering)

Vol. 17, No : 2, Oktober 2020 , p-ISSN:1907-5243, e-ISSN: 2655-8416

\begin{tabular}{|c|c|c|c|c|c|}
\hline & & Indikator & Rating & Bobot & Rating $\times$ Bobot \\
\hline & & Usaha & 85 & 2 & 170 \\
\hline & & Frustasi & 70 & 1 & 70 \\
\hline & & \multicolumn{3}{|c|}{ Total } & 1.260 \\
\hline \multirow[t]{7}{*}{3.} & Pekerja Punch (3) & Kebutuhan Mental & 80 & 4 & 320 \\
\hline & & Kebutuhan Fisik & 90 & 3 & 270 \\
\hline & & Kebutuhan Waktu & 80 & 2 & 160 \\
\hline & & Performansi & 75 & 2 & 150 \\
\hline & & Usaha & 80 & 3 & 240 \\
\hline & & Frustasi & 80 & 1 & 80 \\
\hline & & \multicolumn{3}{|c|}{ Total } & 1.220 \\
\hline \multirow[t]{7}{*}{4.} & Pekerja Milling-Drilling (4) & Kebutuhan Mental & 75 & 4 & 300 \\
\hline & & Kebutuhan Fisik & 65 & 3 & 195 \\
\hline & & Kebutuhan Waktu & 80 & 3 & 240 \\
\hline & & Performansi & 75 & 1 & 75 \\
\hline & & Usaha & 70 & 3 & 210 \\
\hline & & Frustasi & 60 & 0 & 0 \\
\hline & & \multicolumn{3}{|c|}{ Total } & 1.020 \\
\hline \multirow{7}{*}{\multicolumn{2}{|c|}{ Pekerja Potong/Cutting (5) }} & Kebutuhan Mental & 85 & 4 & 340 \\
\hline & & Kebutuhan Fisik & 90 & 4 & 360 \\
\hline & & Kebutuhan Waktu & 90 & 3 & 270 \\
\hline & & Performansi & 85 & 2 & 170 \\
\hline & & Usaha & 85 & 2 & 170 \\
\hline & & Frustasi & 65 & 1 & 65 \\
\hline & & \multicolumn{3}{|c|}{ Total } & 1.375 \\
\hline
\end{tabular}

Data denyut jantung setelah (after) usulan implementasi dari kelima pekerja di Departemen Machine Shop dapat dilihat pada Tabel 3.7.

Tabel 3.7. Data Denyut Jantung Pekerja Bubut (1) Setelah (Before) Usulan Implementasi

\begin{tabular}{|c|c|c|c|c|c|c|c|c|}
\hline $\begin{array}{l}\text { Tanggal } \\
\text { Nama } \\
\text { Umur }\end{array}$ & $\begin{array}{l}: 228-26 \mathrm{Ju} \\
: \text { Pekerja Bu} \\
: 35 \text { tahun }\end{array}$ & & & & & & & \\
\hline Hari ke- & $\begin{array}{c}\text { Waktu } \\
\text { Pengam- } \\
\text { bilan Data }\end{array}$ & $\begin{array}{l}\text { Denyut } \\
\text { Jantung } \\
\text { Sebelum } \\
\text { Kerja } \\
\text { (Denyut/ } \\
\text { menit) }\end{array}$ & $\begin{array}{c}\text { Waktu } \\
\text { Pengam- } \\
\text { bilan Data }\end{array}$ & $\begin{array}{c}\text { Denyut } \\
\text { Jantung } \\
\text { Selama } \\
\text { Kerja } \\
\text { (Denyut/ } \\
\text { menit) }\end{array}$ & $\begin{array}{c}\text { Waktu } \\
\text { Pengam- } \\
\text { bilan Data }\end{array}$ & $\begin{array}{c}\text { Denyut } \\
\text { Jantung } \\
\text { Sebelum } \\
\text { Kerja } \\
\text { (Denyut/ } \\
\text { menit) }\end{array}$ & $\begin{array}{l}\text { Waktu } \\
\text { Pengam- } \\
\text { bilan } \\
\text { Data }\end{array}$ & $\begin{array}{c}\text { Denyut } \\
\text { Jantung } \\
\text { Selama } \\
\text { Kerja } \\
\text { (Denyut/ } \\
\text { menit) }\end{array}$ \\
\hline 1 & 07.22 & 75 & 11.00 & 102 & 12.15 & 76 & 15.20 & 108 \\
\hline 2 & 07.12 & 74 & 11.30 & 97 & 12.15 & 72 & 15.05 & 103 \\
\hline 3 & 07.15 & 70 & 11.25 & 105 & 12.20 & 75 & 15.25 & 98 \\
\hline 4 & 07.23 & 71 & 11.15 & 104 & 12.05 & 73 & 15.20 & 103 \\
\hline 5 & 07.15 & 70 & 11.20 & 107 & 12.35 & 70 & 15.35 & 106 \\
\hline
\end{tabular}

Tabel 3.8. Data Denyut Jantung Pekerja Scrab (2) Setelah (After) Usulan Implementasi

\begin{tabular}{|c|c|c|c|c|c|c|c|c|}
\hline $\begin{array}{l}\text { Tanggal } \\
\text { Nama } \\
\text { Umur }\end{array}$ & $\begin{array}{l}: 22-26 \text { Juli } \\
: \text { Pekerja } S c \\
: 32 \text { tahun }\end{array}$ & & & & & & & \\
\hline Hari ke- & $\begin{array}{c}\text { Waktu } \\
\text { Pengam- } \\
\text { bilan Data }\end{array}$ & $\begin{array}{l}\text { Denyut } \\
\text { Jantung } \\
\text { Sebelum } \\
\text { Kerja } \\
\text { (Denyut/ } \\
\text { menit) }\end{array}$ & $\begin{array}{c}\text { Waktu } \\
\text { Pengam- } \\
\text { bilan Data }\end{array}$ & $\begin{array}{l}\text { Denyut } \\
\text { Jantung } \\
\text { Selama } \\
\text { Kerja } \\
\text { (Denyut/ } \\
\text { menit) }\end{array}$ & $\begin{array}{c}\text { Waktu } \\
\text { Pengam- } \\
\text { bilan Data }\end{array}$ & $\begin{array}{c}\text { Denyut } \\
\text { Jantung } \\
\text { Sebelum } \\
\text { Kerja } \\
\text { (Denyut/ } \\
\text { menit) }\end{array}$ & $\begin{array}{c}\text { Waktu } \\
\text { Pengam- } \\
\text { bilan } \\
\text { Data }\end{array}$ & $\begin{array}{c}\text { Denyut } \\
\text { Jantung } \\
\text { Selama } \\
\text { Kerja } \\
\text { (Denyut/ } \\
\text { menit) }\end{array}$ \\
\hline 1 & 07.10 & 73 & 11.00 & 110 & 12.45 & 75 & 15.10 & 106 \\
\hline 2 & 07.13 & 75 & 11.30 & 108 & 12.40 & 73 & 15.35 & 105 \\
\hline 3 & 07.23 & 76 & 11.25 & 106 & 12.25 & 72 & 15.40 & 108 \\
\hline 4 & 07.15 & 71 & 11.15 & 112 & 12.45 & 72 & 15.45 & 107 \\
\hline 5 & 07.20 & 74 & 11.20 & 106 & 12.50 & 74 & 15.15 & 112 \\
\hline
\end{tabular}


(Civil Engineeering, Elektrical Engineeering and Industrial Engineering)

Vol. 17, No : 2, Oktober 2020 , p-ISSN:1907-5243, e-ISSN: 2655-8416

Tabel 3.9. Data Denyut Jantung Pekerja Punch (3) Setelah (After) Usulan Implementasi

\begin{tabular}{|c|c|c|c|c|c|c|c|c|}
\hline $\begin{array}{l}\text { Tanggal } \\
\text { Nama } \\
\text { Umur }\end{array}$ & $\begin{array}{l}: 22-26 \mathrm{Jul} \\
: \text { Pekerja } P \boldsymbol{P} \\
: 37 \text { tahun }\end{array}$ & (3) & & & & & & \\
\hline Hari ke- & $\begin{array}{c}\text { Waktu } \\
\text { Pengam- } \\
\text { bilan Data }\end{array}$ & $\begin{array}{c}\text { Denyut } \\
\text { Jantung } \\
\text { Sebelum } \\
\text { Kerja } \\
\text { (Denyut/ } \\
\text { menit) }\end{array}$ & $\begin{array}{c}\text { Waktu } \\
\text { Pengam- } \\
\text { bilan Data }\end{array}$ & $\begin{array}{c}\text { Denyut } \\
\text { Jantung } \\
\text { Selama } \\
\text { Kerja } \\
\text { (Denyut/ } \\
\text { menit) }\end{array}$ & $\begin{array}{c}\text { Waktu } \\
\text { Pengam- } \\
\text { bilan Data }\end{array}$ & $\begin{array}{c}\text { Denyut } \\
\text { Jantung } \\
\text { Sebelum } \\
\text { Kerja } \\
\text { (Denyut/ } \\
\text { menit) }\end{array}$ & $\begin{array}{c}\text { Waktu } \\
\text { Pengam- } \\
\text { bilan } \\
\text { Data }\end{array}$ & $\begin{array}{c}\text { Denyut } \\
\text { Jantung } \\
\text { Selama } \\
\text { Kerja } \\
\text { (Denyut/ } \\
\text { menit) }\end{array}$ \\
\hline 1 & 07.23 & 63 & 11.35 & 102 & 12.26 & 61 & 15.50 & 103 \\
\hline 2 & 07.10 & 67 & 11.15 & 105 & 12.22 & 71 & 1525 & 107 \\
\hline 3 & 07.29 & 71 & 11.50 & 96 & 12.15 & 72 & 1530 & 105 \\
\hline 4 & 07.17 & 68 & 11.24 & 95 & 12.52 & 68 & 15.32 & 101 \\
\hline 5 & 07.15 & 64 & 11.42 & 100 & 12.18 & 70 & 15.21 & 98 \\
\hline
\end{tabular}

Tabel 3.10. Data Denyut Jantung Pekerja Milling-Drilling (4) Setelah (After) Usulan Implementasi

\begin{tabular}{|c|c|c|c|c|c|c|c|c|}
\hline $\begin{array}{l}\text { Tanggal } \\
\text { Nama } \\
\text { Umur }\end{array}$ & $\begin{array}{l}: 22-26 \mathrm{Jul} \\
: \text { Pekerja } M \\
: 26 \text { tahun }\end{array}$ & 9 -Drilling & & & & & & \\
\hline Hari ke- & $\begin{array}{c}\text { Waktu } \\
\text { Pengam- } \\
\text { bilan Data }\end{array}$ & $\begin{array}{c}\text { Denyut } \\
\text { Jantung } \\
\text { Sebelum } \\
\text { Kerja } \\
\text { (Denyut/ } \\
\text { menit) }\end{array}$ & $\begin{array}{c}\text { Waktu } \\
\text { Pengam- } \\
\text { bilan Data }\end{array}$ & $\begin{array}{c}\text { Denyut } \\
\text { Jantung } \\
\text { Selama } \\
\text { Kerja } \\
\text { (Denyut/ } \\
\text { menit) }\end{array}$ & $\begin{array}{c}\text { Waktu } \\
\text { Pengam- } \\
\text { bilan Data }\end{array}$ & $\begin{array}{c}\text { Denyut } \\
\text { Jantung } \\
\text { Sebelum } \\
\text { Kerja } \\
\text { (Denyut/ } \\
\text { menit) }\end{array}$ & $\begin{array}{l}\text { Waktu } \\
\text { Pengam- } \\
\text { bilan } \\
\text { Data }\end{array}$ & $\begin{array}{c}\text { Denyut } \\
\text { Jantung } \\
\text { Selama } \\
\text { Kerja } \\
\text { (Denyut/ } \\
\text { menit) }\end{array}$ \\
\hline 1 & 07.25 & 60 & 11.21 & 97 & 12.30 & 63 & 15.35 & 98 \\
\hline 2 & 07.12 & 64 & 11.15 & 92 & 12.11 & 72 & 15.42 & 103 \\
\hline 3 & 07.12 & 65 & 11.32 & 98 & 12.30 & 69 & 15.17 & 97 \\
\hline 4 & 07.13 & 66 & 11.45 & 90 & 12.26 & 70 & 15.12 & 92 \\
\hline 5 & 07.25 & 65 & 11.25 & 94 & 12.54 & 67 & 15.23 & 97 \\
\hline
\end{tabular}

Tabel 3.11. Data Denyut Jantung Pekerja Potong (Cutting) (5) Setelah (After) Usulan Implementasi

\begin{tabular}{|c|c|c|c|c|c|c|c|c|}
\hline $\begin{array}{l}\text { Tanggal } \\
\text { Nama } \\
\text { Umur } \\
\end{array}$ & $\begin{array}{l}\text { : } 22-26 \text { Juli } \\
\text { : Pekerja Po } \\
: 28 \text { tahun }\end{array}$ & Cutting & & & & & & \\
\hline Hari ke- & $\begin{array}{c}\text { Waktu } \\
\text { Pengam- } \\
\text { bilan Data }\end{array}$ & $\begin{array}{c}\text { Denyut } \\
\text { Jantung } \\
\text { Sebelum } \\
\text { Kerja } \\
\text { (Denyut/ } \\
\text { menit) }\end{array}$ & $\begin{array}{c}\text { Waktu } \\
\text { Pengam- } \\
\text { bilan Data }\end{array}$ & $\begin{array}{l}\text { Denyut } \\
\text { Jantung } \\
\text { Selama } \\
\text { Kerja } \\
\text { (Denyut/ } \\
\text { menit) }\end{array}$ & $\begin{array}{c}\text { Waktu } \\
\text { Pengam- } \\
\text { bilan Data }\end{array}$ & $\begin{array}{l}\text { Denyut } \\
\text { Jantung } \\
\text { Sebelum } \\
\text { Kerja } \\
\text { (Denyut/ } \\
\text { menit) }\end{array}$ & $\begin{array}{l}\text { Waktu } \\
\text { Pengam- } \\
\text { bilan } \\
\text { Data }\end{array}$ & $\begin{array}{l}\text { Denyut } \\
\text { Jantung } \\
\text { Selama } \\
\text { Kerja } \\
\text { (Denyut / } \\
\text { menit) }\end{array}$ \\
\hline 1 & 07.27 & 60 & 11.41 & 97 & 12.20 & 70 & 15.02 & 95 \\
\hline 2 & 07.29 & 68 & 11.52 & 88 & 12.32 & 67 & 15.23 & 98 \\
\hline 3 & 07.10 & 64 & 11.25 & 92 & 12.24 & 70 & 15.10 & 103 \\
\hline 4 & 07.12 & 62 & 11.07 & 94 & 12.41 & 67 & 15.14 & 93 \\
\hline 5 & 07.10 & 64 & 11.40 & 90 & 12.45 & 70 & 15.05 & 96 \\
\hline
\end{tabular}

Pengambilan data kuesioner dilakukan setelah pekerja menerapkan usulan implementasi selama 2 minggu agar pekerja sudah terbiasa dengan pekerjaan yang dilakukan. Hasil pengisian lembar kuesioner NASA-TLX oleh pekerja di Departemen Machine Shop dapat dilihat pada Tabel 3.12.

Tabel 3.12. Data Kuesioner NASA-TLX Setelah (After) Usulan Implementasi

\begin{tabular}{|c|c|c|c|c|c|}
\hline No. & Nama Pekerja & Indikator & Rating & Bobot & Rating $\times$ Bobot \\
\hline \multirow[t]{6}{*}{1.} & Pekerja Bubut (1) & Kebutuhan Mental & 60 & 3 & 180 \\
\hline & & Kebutuhan Fisik & 65 & 3 & 195 \\
\hline & & Kebutuhan Waktu & 80 & 3 & 240 \\
\hline & & Performansi & 65 & 3 & 195 \\
\hline & & Usaha & 70 & 2 & 140 \\
\hline & & Frustasi & 55 & 1 & 55 \\
\hline
\end{tabular}


Jurnal TEKNO

(Civil Engineeering, Elektrical Engineeering and Industrial Engineering)

Vol. 17, No : 2, Oktober 2020 , p-ISSN:1907-5243, e-ISSN: 2655-8416

\begin{tabular}{|c|c|c|c|c|c|}
\hline No. & Nama Pekerja & Indikator & Rating & Bobot & Rating $\times$ Bobot \\
\hline \multirow[t]{7}{*}{2.} & Pekerja $S_{c r a b}(2)$ & Kebutuhan Mental & 65 & 2 & 130 \\
\hline & & Kebutuhan Fisik & 70 & 4 & 280 \\
\hline & & Kebutuhan Waktu & 90 & 2 & 180 \\
\hline & & Performansi & 70 & 3 & 210 \\
\hline & & Usaha & 80 & 4 & 320 \\
\hline & & Frustasi & 60 & 0 & 0 \\
\hline & & \multicolumn{3}{|c|}{ Total } & 1.120 \\
\hline \multirow[t]{7}{*}{3.} & Pekerja Punch (3) & Kebutuhan Mental & 50 & 2 & 100 \\
\hline & & Kebutuhan Fisik & 70 & 4 & 280 \\
\hline & & Kebutuhan Waktu & 80 & 3 & 240 \\
\hline & & Performansi & 70 & 1 & 70 \\
\hline & & Usaha & 70 & 3 & 210 \\
\hline & & Frustasi & 55 & 2 & 110 \\
\hline & & \multicolumn{3}{|c|}{ Total } & 1.010 \\
\hline \multirow[t]{7}{*}{4.} & Pekerja Milling-Drilling (4) & Kebutuhan Mental & 55 & 3 & 165 \\
\hline & & Kebutuhan Fisik & 75 & 3 & 225 \\
\hline & & Kebutuhan Waktu & 80 & 4 & 320 \\
\hline & & Performansi & 60 & 2 & 120 \\
\hline & & Usaha & 70 & 1 & 70 \\
\hline & & Frustasi & 50 & 1 & 50 \\
\hline & & \multicolumn{3}{|c|}{ Total } & 950 \\
\hline \multirow[t]{7}{*}{5.} & Pekerja Potong/Cutting (5) & Kebutuhan Mental & 40 & 2 & 80 \\
\hline & & Kebutuhan Fisik & 65 & 3 & 195 \\
\hline & & Kebutuhan Waktu & 80 & 4 & 320 \\
\hline & & Performansi & 75 & 1 & 75 \\
\hline & & Usaha & 65 & 4 & 380 \\
\hline & & Frustasi & 65 & 1 & 65 \\
\hline & & \multicolumn{3}{|c|}{ Total } & 1.115 \\
\hline
\end{tabular}

Aktivitas di Departemen Machine Shop melakukan proses kegiatan pengolahan bahan baku berbentuk plat, pipa/ as sesuai dengan kebutuhan/ kegunaan dengan pengoperasian mesin untuk menjadi bahan siap dilas atau menjadi komponen spare part. Aktivitas/ kegiatan pekerjaan di Departemen Machine Shop terbagi menjadi 5 aktivitas pekerjaan yaitu; aktivitas bubut, scrab, punch, milling-driling, dan potong (cutting). Bubut: proses pembentukan suatu bahan/ barang berupa as, pipa menjadi suatu bentuk yang sesuai dengan kebutuhan menjadi komponen yang siap diwelding/ ke proses selanjutnya. Scrab: proses pengerjaan pembentukan/ penghalusan permukaan yang sesuai dengan fungsi dan kegunaan dalam proses selanjutnya. Punch: proses mengolah bahan potongan menjadi bahan yang mempunyai bentuk sesuai dengan cetakan/ dies yang terpasang di mesin. Milling-Drilling: proses melubangi suatu bahan/ barang sesuai dengan besarnya mata bor/ milling yang digunakan pada mesin. Dan Potong (Cutting): proses yang membentuk ukuran dan bentuk potong suatu bahan yang akan dilas atau ke proses selanjutnya

Denyut jantung sebelum kerja dan selama kerja akan digunakan untuk menghitung \%CVL pekerja yang didapatkan berdasarkan perhitungan rata-rata jumlah denyut nadi per menit dari 5 hari kerja untuk masing-masing pekerja di Departemen Macbine Shop, disajikan pada Tabel 3.13.

Tabel 3.13. Hasil Denyut Jantung Pekerja Sebelum Kerja dan Selama Kerja Sebelum (Before) dan Sesudah (After) Usulan Implementasi

\begin{tabular}{llccccc}
\hline No. & Nama Pekerja & $\begin{array}{c}\text { Usia } \\
\text { (Tahun } \\
\text { ) }\end{array}$ & \multicolumn{2}{c}{$\begin{array}{c}\text { Denyut Jantung } \\
\text { Sebelum Kerja } \\
\text { (Denyut/menit) }\end{array}$} & \multicolumn{2}{c}{$\begin{array}{c}\text { Denyut Jantung Selama } \\
\text { Kerja (Denyut/menit) }\end{array}$} \\
\hline & & & Sebelum & Usulan & Sebelum & Usulan \\
\hline 1 & Pekerja Bubut (1) & 35 & 70,8 & 72,6 & 112,1 & 105,7 \\
2 & Pekerja Scrab (2) & 32 & 76,5 & 73,5 & 121,1 & 115,1 \\
3 & Pekerja Punch (3) & 37 & 72,8 & 72,5 & 113,7 & 109,2 \\
4 & Pekerja Milling-Drilling (4) & 26 & 71,8 & 72,1 & 109,6 & 98,9 \\
5 & Pekerja Potong/Cutting (5) & 28 & 68,9 & 70,1 & 115,2 & 110,0 \\
\hline
\end{tabular}


Berdasarkan hasil denyut jantung yang ditunjukkan pada Tabel 3.13. dapat dilihat bahwa denyut jantung/nadi sebelum kerja tertinggi diterima oleh Pekerja scrab (2) yaitu sebesar 76,5 denyut/menit. Denyut jantung terendah sebelum kerja diterima oleh Pekerja Potong (Cutting) (5) dengan denyut jantung sebesar 68,9 denyut/menit. Sedangkan denyut jantung/nadi selama kerja tertinggi diterima oleh Pekerja scrab (2) yaitu sebesar 121,1 denyut/menit. Denyut jantung terendah diterima oleh Pekerja Milling-Drilling (4) dengan denyut jantung kerja sebesar 109,6 denyut/menit. Pekerjaan di Departemen Machine Shop yang diamati, aktivitas pekerjaan milling-drilling memiliki beban kerja fisik lebih ringan karena dalam aktivitas ini pekerja hanya melubangi suatu bahan/ barang sesuai dengan besarnya mata bor/ milling yang digunakan pada mesin. Berbeda dengan pekerja scrab melakukan pengerjaan pembentukan/ penghalusan permukaan yang sesuai dengan fungsi dan kegunaan dalam proses selanjutnya secara berulang-ulang (repetitive work) hingga kehalusan permukaan sudah sesuai dengan standar. Pekerja dengan beban kerja fisik yang lebih berat memungkinkan memiliki denyut jantung yang lebih banyak/ besar setiap menitnya dibandingkan pekerja dengan beban kerja fisik yang lebih berat meskipun usianya lebih muda. Hal ini dapat dilihat pada perbandingan denyut jantung antara pekerja potong (cutting) (5) yang berusia 28 tahun dengan pekerja millingdrilling (4) yang berusia 26 tahun. Perhitungan \% CVL dilakukan pada masing-masing pekerja untuk mengetahui klasifikasi beban kerja fisik. Hasil perhitungan \% CVL pekerja dapat dilihat lebih rinci pada Tabel 3.14.

Tabel 3.14. Persentase CVL Pekerja Sebelum Kerja dan Selama Kerja sebelum (Before) dan Sesudah (After) Usulan Implementasi

\begin{tabular}{|c|c|c|c|c|c|c|c|c|c|c|}
\hline \multirow[t]{2}{*}{ No. } & \multirow[t]{2}{*}{ Nama Pekerja } & \multirow[t]{2}{*}{$\begin{array}{c}\text { Usia } \\
\text { (Tahun) }\end{array}$} & \multicolumn{2}{|c|}{ Denyut Max } & \multicolumn{2}{|c|}{$\begin{array}{l}\text { Denyut Jantung } \\
\text { Sebelum Kerja } \\
\text { (Denyut/menit) }\end{array}$} & \multicolumn{2}{|c|}{$\begin{array}{l}\text { Denyut jantung } \\
\text { Selama Kerja } \\
\text { (Denyut/menit) }\end{array}$} & \multicolumn{2}{|c|}{$\% \mathrm{CVL}$} \\
\hline & & & Before & After & Before & After & Before & After & Before & After \\
\hline 1 & Pekerja Bubut (1) & 35 & 185 & 185 & 70,8 & 72,6 & 112,1 & 105,7 & 36,16 & 29,45 \\
\hline 2 & Pekerja Scrab (2) & 32 & 188 & 180 & 76,5 & 73,5 & 121,1 & 115,1 & 40,00 & 39,06 \\
\hline 3 & Pekerja Punch (3) & 37 & 183 & 182 & 72,8 & 72,5 & 113,7 & 109,2 & 37,11 & 31,52 \\
\hline 4 & Pekerja Milling-Drilling (4) & 26 & 194 & 192 & 71,8 & 72,1 & 109,6 & 98,9 & 30,93 & 22,35 \\
\hline 5 & Pekerja Potong/Cutting (5) & 28 & 192 & 188 & 68,9 & 70,1 & 115,2 & 110,0 & 37,61 & 33,84 \\
\hline
\end{tabular}

Berdasarkan hasil perhitungan pada Tabel 3.14. didapatkan bahwa kelima pekerja di Departemen Machine Shop memiliki \%CVL sebelum (before) usulan implementasi adalah sebesar $>30 \%$ oleh sebab itu kelima pekerja diklasifikasikan ke dalam pekerjaan yang dilakukan diperlukan perbaikan. Sedangkan untuk pekerja yang memiliki nilai \%CVL $<30$ tidak ada sehingga pekerja yang masuk ke kategori pekerja tidak terlalu kelelahan saat bekerja tidak ada. Sedangkan \%CVL setelah (after) usulan implementasi kelima pekerja mengalami penurunan, yaitu; pekerja bubut (1) sebesar 29,45\% (turun 6,71\%), pekerja scrab (2) sebesar $39,06 \%$ (turun $0,94 \%$ ), pekerja punch (3) sebesar 31,52\% (turun 5,59\%), pekerja milling-drilling (4) sebesar $22,35 \%$ (turun 8,58\%), dan pekerja potong/cutting (5) sebesar 33,84\% (turun 3,77\%).

Data penilaian beban kerja mental menggunakan kuesioner NASA-TLX yang diisi oleh pekerja di Departemen Machine Shop diolah dengan menghitung nilai WWL (Weighted Work Load) dari masing-masing operator. Langkah-langkah perhitungan skor NASA-TLX adalah sebagai berikut; a) Menghitung Skala Pembobotan dengan menghitung jumlah tally dari setiap indikator yang dirasa paling dominan yang mempengaruhi pekerja saat melakukan aktivitas/ kegiatan pekerjaan. Jumlah tally ini akan digunakan sebagai bobot untuk tiap indikator beban kerja mental, b) Menghitung Rating dimana responden memberikan rating pada keenam indikator beban kerja mental. Rating yang diberikan bersifat subyektif tergantung dengan beban mental yang diterima oleh responden tersebut, c) Perhitungan nilai produk didapat dengan mengalikan rating dengan bobot faktor untuk masing-masing indicator, d) Menghitung nilai WWL (Weighted Work Load) diperoleh dengan menjumlahkan kelima nilai produk yang sudah dihitung sebelumnya, e) Menghitung Rata-rata WWL didapat dengan membagi WWL dengan jumlah bobot total, dan f) Intepretasi Skor. Berdasarkan penjelasan Hart dan Staveland (1981) dalam teori NASA-TLX, skor beban kerja yang diperoleh terbagi dalam 3 klasifikasi yaitu, jilai nilai $<50$ maka beban pekerjaan dianggap ringan, jika nilai 50-80 maka beban kerja yang diterima dinyatakan sedang, sedangkan untuk nilai $>80$ maka beban kerja yang diterima dinyatakan berat. Perhitungan nilai produk dapat dilihat pada Tabel 3.15 dan Tabel 3.16. Intepretasi skor yang diperoleh oleh masing-masing pekerja dapat dilihat pada Tabel 3.16. 
Jurnal TEKNO

(Civil Engineeering, Elektrical Engineeering and Industrial Engineering)

Vol. 17, No : 2, Oktober 2020 , p-ISSN:1907-5243, e-ISSN: 2655-8416

Tabel 3.15. Perhitungan Nilai Produk Sebelum (Before) Usulan Implementasi

\begin{tabular}{|c|c|c|c|c|c|c|c|c|c|c|}
\hline \multirow{3}{*}{ No. } & \multirow{3}{*}{ Nama Pekerja } & \multicolumn{9}{|c|}{ Nilai Produk } \\
\hline & & \multicolumn{3}{|c|}{ KM } & \multicolumn{3}{|c|}{ KF } & \multicolumn{3}{|c|}{ KW } \\
\hline & & $\mathbf{B}$ & $\mathbf{R}$ & NP & B & $\mathbf{R}$ & NP & B & $\mathbf{R}$ & NP \\
\hline 1 & Pekerja Bubut (1) & 3 & 90 & 270 & 4 & 90 & 360 & 3 & 85 & 255 \\
\hline 2 & Pekerja $S_{c r a b}(2)$ & 4 & 90 & 360 & 4 & 85 & 340 & 2 & 85 & 170 \\
\hline 3 & Pekerja Punch (3) & 4 & 80 & 320 & 3 & 90 & 270 & 2 & 80 & 160 \\
\hline 4 & Pekerja Milling-Drilling (4) & 4 & 75 & 300 & 3 & 65 & 195 & 3 & 80 & 240 \\
\hline 5 & Pekerja Potong/Cutting (5) & 4 & 85 & 340 & 4 & 90 & 360 & 3 & 90 & 270 \\
\hline
\end{tabular}

Tabel 3.15. Perhitungan Nilai Produk Sebelum (Before) Usulan Implementasi (Lanjutan)

\begin{tabular}{|c|c|c|c|c|c|c|c|c|c|c|}
\hline \multirow{3}{*}{ No. } & \multirow{3}{*}{ Nama Pekerja } & \multicolumn{9}{|c|}{ Nilai Produk } \\
\hline & & \multicolumn{3}{|c|}{$\mathbf{P}$} & \multicolumn{3}{|c|}{ TU } & \multicolumn{3}{|c|}{ TF } \\
\hline & & B & $\mathbf{R}$ & NP & B & $\mathbf{R}$ & NP & B & $\mathbf{R}$ & NP \\
\hline 1 & Pekerja Bubut (1) & 2 & 75 & 150 & 2 & 75 & 150 & 1 & 55 & 55 \\
\hline 2 & Pekerja Scrab (2) & 2 & 75 & 150 & 2 & 85 & 170 & 1 & 70 & 70 \\
\hline 3 & Pekerja Punch (3) & 2 & 75 & 150 & 3 & 80 & 240 & 1 & 80 & 80 \\
\hline 4 & Pekerja Milling-Drilling (4) & 1 & 75 & 75 & 3 & 70 & 210 & 0 & 60 & 0 \\
\hline 5 & Pekerja Potong/Cutting (5) & 2 & 85 & 170 & 2 & 95 & 190 & 1 & 65 & 65 \\
\hline
\end{tabular}

Keterangan: $\mathrm{B}=$ Bobot, $\mathrm{R}=$ Rating, $\mathrm{NP}=$ Nilai Produk

Analisis penyebab masalah dilakukan dengan menggunakan Fault Tree Analysis (FTA). Sumbersumber yang menyebabkan penurunan tingkat fokus pekerja dapat digambarkan dalam bentuk model pohon kesalahan pada Gambar 3.1, dan Gambar 3.2 serta pemberian usulan implementasi berdasarkan FTA disajikan pada Tabel 3.1

Tabel 3.16. Perhitungan Nilai Produk Setelah (After) Usulan Implementasi

\begin{tabular}{llccccccccc}
\hline & & \multicolumn{9}{c}{ Nilai Produk } \\
\cline { 3 - 10 } No. & \multirow{3}{*}{ Nama Pekerja } & KM & R & NP & B & R & NP & B & R & NP \\
\cline { 2 - 10 } & & 3 & 60 & 180 & 3 & 65 & 195 & 3 & 80 & 240 \\
\hline 1 & Pekerja Bubut (1) & 2 & 65 & 130 & 4 & 70 & 280 & 2 & 90 & 180 \\
2 & Pekerja Scrab (2) & 2 & 50 & 100 & 4 & 70 & 280 & 3 & 80 & 240 \\
3 & Pekerja Punch (3) & 3 & 55 & 165 & 3 & 75 & 225 & 4 & 80 & 320 \\
4 & Pekerja Milling-Drilling (4) & 2 & 40 & 80 & 3 & 65 & 195 & 4 & 80 & 320 \\
5 & Pekerja Potong/Cutting (5) & 2 &
\end{tabular}

Tabel 3.16. Perhitungan Nilai Produk Setelah (After) Usulan Implementasi (Lanjutan)

\begin{tabular}{|c|c|c|c|c|c|c|c|c|c|c|}
\hline \multirow{3}{*}{ No. } & \multirow{3}{*}{ Nama Pekerja } & \multicolumn{9}{|c|}{ Nilai Produk } \\
\hline & & \multicolumn{3}{|c|}{$\mathbf{P}$} & \multicolumn{3}{|c|}{ TU } & \multicolumn{3}{|c|}{ TF } \\
\hline & & $\mathbf{B}$ & $\mathbf{R}$ & NP & B & $\mathbf{R}$ & NP & B & $\mathbf{R}$ & NP \\
\hline 1 & Pekerja Bubut (1) & 3 & 65 & 195 & 2 & 70 & 140 & 1 & 55 & 55 \\
\hline 2 & Pekerja Scrab (2) & 3 & 70 & 210 & 4 & 80 & 320 & 0 & 60 & 0 \\
\hline 3 & Pekerja Punch (3) & 1 & 70 & 70 & 3 & 70 & 210 & 2 & 55 & 110 \\
\hline 4 & Pekerja Milling-Drilling (4) & 2 & 60 & 120 & 1 & 70 & 70 & 1 & 50 & 50 \\
\hline 5 & Pekerja Potong/Cutting (5) & 1 & 75 & 75 & 4 & 95 & 380 & 1 & 65 & 65 \\
\hline
\end{tabular}




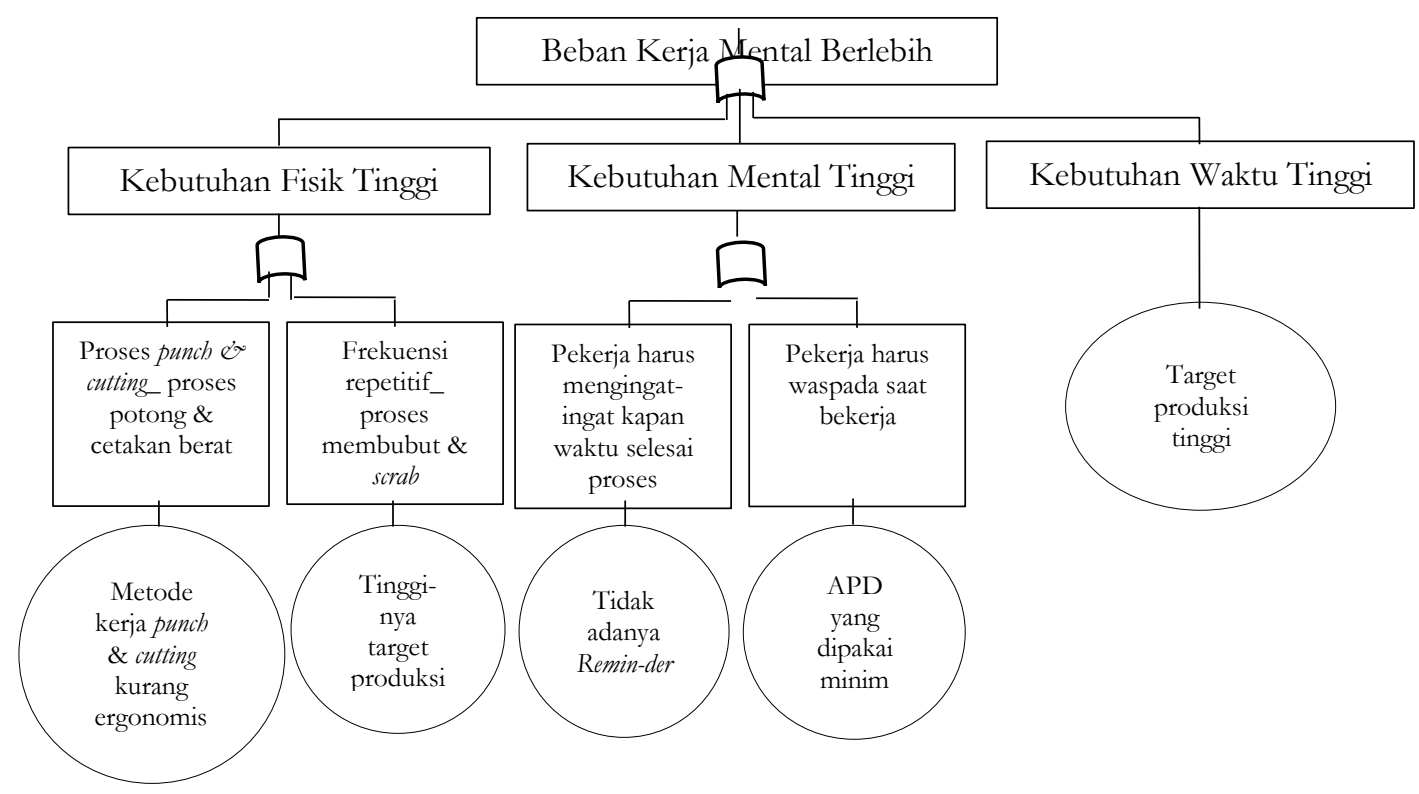

Gambar 4.1. Fault Tree Analysis Beban Kerja Mental Pekerja di Departemen Machine Shop

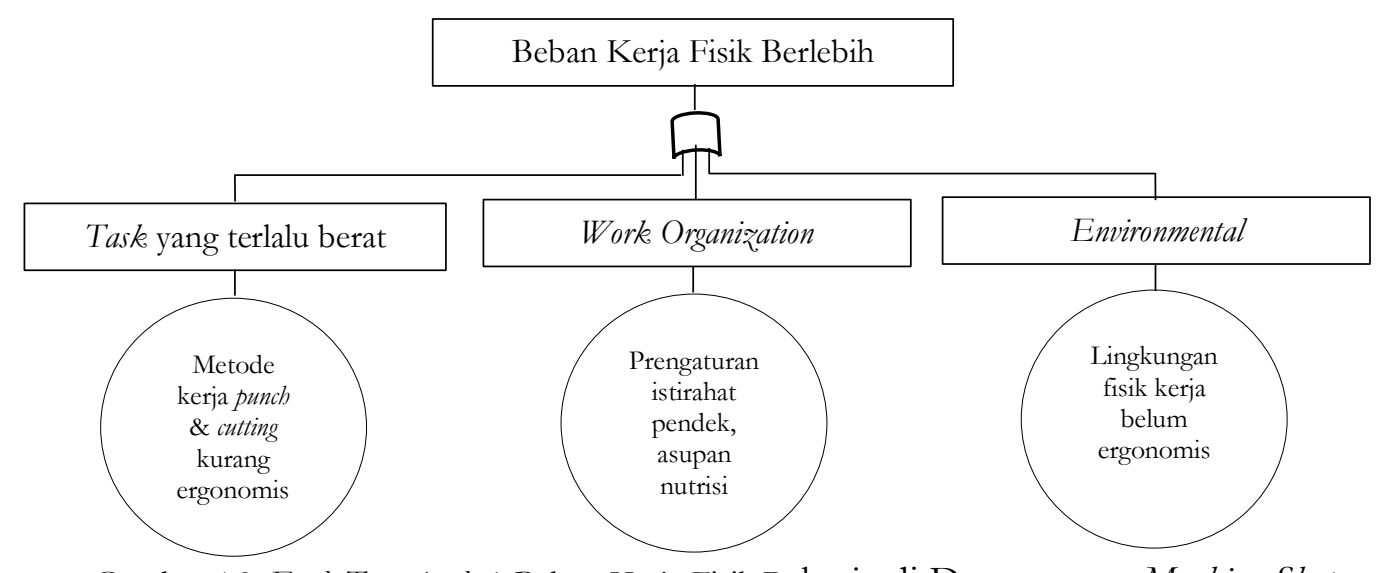

Gambar 4.2. Fault Tree Analysis Beban Kerja Fisik Pekerja di Departemen Machine Shop

Tabel 4.16. Intepretasi Sebelum (Before) dan Setelah (After) Usulan Implementasi

\begin{tabular}{|cccccccc|}
\hline \multirow{2}{*}{ No. } & \multirow{2}{*}{ Nama Pekerja } & \multicolumn{2}{c}{ Nilai WWL } & \multicolumn{2}{c|}{ Skor NASA-TLX } & \multicolumn{2}{c|}{ Keterangan } \\
\cline { 3 - 7 } & & Before & After & Before & After & Before & After \\
\hline 1 & Pekerja Bubut (1) & 1.240 & 1.005 & 82,67 & 67,00 & Berat & Sedang \\
2 & Pekerja Scrab (2) & 1.260 & 1.120 & 84,00 & 74,67 & Berat & Sedang \\
3 & Pekerja Punch (3) & 1.220 & 1.010 & 81,33 & 67,33 & Berat & Sedang \\
4 & Pekerja Milling-Drilling (4) & 1.020 & 950 & 72,86 & 67,87 & Sedang & Sedang \\
5 & Pekerja Potong/Cutting (5) & 1.375 & 1.115 & 85,94 & 74,33 & Berat & Sedang \\
\hline
\end{tabular}


Tabel 4.17. Pemberian Usulan Implementasi (After) Berdasarkan FTA

\begin{tabular}{|c|c|c|c|}
\hline $\begin{array}{l}\text { Potensial } \\
\text { Cause }\end{array}$ & $\begin{array}{c}\text { Akar dari } \\
\text { Potensial Cause }\end{array}$ & Keadaan dalam Perusahaan & Usulan Implementasi \\
\hline $\begin{array}{l}\text { Beban kerja } \\
\text { mental berlebih }\end{array}$ & $\begin{array}{l}\text { Tidak adanya } \\
\text { Reminder }\end{array}$ & $\begin{array}{l}\text { Di lantai produksi belum ada alat } \\
\text { yang dapat membantu pekerja } \\
\text { dalam hal meningat kapan waktu } \\
\text { yang tepat saat proses start dan } \\
\text { finish sesuai standar. }\end{array}$ & $\begin{array}{l}\text { Pekerja di Departemen Machine } \\
\text { Shop dibuatkan jigs dan alat } \\
\text { Reminder agar dapat mengetahui } \\
\text { kapan waktu yang tepat saat } \\
\text { proses start dan finish sesuai } \\
\text { standar }\end{array}$ \\
\hline $\begin{array}{l}\text { Beban kerja } \\
\text { mental berlebih }\end{array}$ & $\begin{array}{l}\text { APD yang } \\
\text { digunakan masih } \\
\text { minim }\end{array}$ & $\begin{array}{l}\text { Perusahaan belum menyediakan } \\
\text { APD yang ergonomis dengan } \\
\text { pekerja \& pekerjaannya }\end{array}$ & $\begin{array}{l}\text { Disediakan APD yang } \\
\text { ergonomis dengan pekerja \& } \\
\text { pekerjaannya, agar pekerja tidak } \\
\text { was-was dan bekerja sehat. }\end{array}$ \\
\hline \multirow[t]{3}{*}{$\begin{array}{l}\text { Beban kerja fisik } \\
\text { berlebih }\end{array}$} & $\begin{array}{l}\text { Pengaturan Task/ } \\
\text { beban kerja belum } \\
\text { dievaluasi \& metode } \\
\text { kerja punch \& cutting } \\
\text { kurang ergonomis }\end{array}$ & $\begin{array}{l}\text { Pekerja di Departemen Machine } \\
\text { Shop belum mengetahui metode } \\
\text { dan alat bantu kerja yang } \\
\text { Ergonomis: ENASE (Efektif, } \\
\text { Nyaman, Aman, Sehat, Efisien) }\end{array}$ & $\begin{array}{l}\text { Evaluasi Task/ beban kerja, dan } \\
\text { perbaikan metode dan alat bantu } \\
\text { kerja di Departemen Machine } \\
\text { Shop yang lebih Ergonomis: } \\
\text { ENASE }\end{array}$ \\
\hline & $\begin{array}{l}\text { Belum menerapkan } \\
\text { Work Organization }\end{array}$ & $\begin{array}{l}\text { Work Organization belum diatur } \\
\text { penjadwalan istirahat pendek, } \\
\text { tambahan asupan nutrisi, dll. }\end{array}$ & $\begin{array}{l}\text { Menerapkan Work Organization } \\
\text { dengan mengatur penjadwalan } \\
\text { istirahat pendek, tambahan } \\
\text { asupan nutrisi, dll. }\end{array}$ \\
\hline & $\begin{array}{l}\text { Environmental } \\
\text { lingkungan fisik } \\
\text { kerja belum } \\
\text { ergonomis: ENASE }\end{array}$ & $\begin{array}{l}\text { Kondisi sirkulasi udara, } \\
\text { penerangan, pewarnaan dinding, } \\
\text { atap, kebisingan masih melebihi } \\
\text { nilai ambang batas }\end{array}$ & $\begin{array}{l}\text { Merancang ulang environmental } \\
\text { lingkungan fisik kerja yang lebih } \\
\text { ergonomis: ENASE. Menambah } \\
\text { ventilasi udara, penerangan (atap } \\
\text { transparan), cat dinding dengan } \\
\text { warna terang, pengaturan } \\
\text { kebisingan, dll. }\end{array}$ \\
\hline
\end{tabular}

Pada Tabel 3.16. diatas dapat dilihat bahwa hampir semua pekerja di Deparrtemen Machine Shop sebelum (before) usulan implementasi memiliki skor NASA-TLX kategori berat semua kecuali pada pekerja millingdrilling (4) kategori sedang. Penurunan skor NASA-TLX sebelum (before) dibandingkan setelah (after) usulan implementasi, yaitu: Pekerja Bubut (1) dari skor 82,67 (kategori berat) turun menjadi 67,00 (turun 15,67) menjadi kategori sedang. Pekerja $S_{c r a b}$ (2) dari skor 84,00 (kategori berat) turun menjadi 74,67 (turun 9,33) menjadi kategori sedang. Pekerja Punch (3) dari skor 81,33 (kategori berat) turun menjadi 67,33 (turun 14) menjadi kategori sedang. Pekerja Milling-Drilling (4) dari skor 72,86 (kategori sedang) turun menjadi 67,87 (turun 4,99) masih dalam kategori sedang. Dan Pekerja Potong/Cutting (5) dari skor 85,94 (kategori berat) turun menjadi 74,33 (turun 11,61) menjadi kategori sedang.

\section{KESIMPULAN DAN SARAN}

\subsection{Kesimpulan}

berikut:

Berdasarkan hasil penelitian yang dilakukan, dapat ditarik kesimpulan sebagai

a. Berdasarkan aspek perhitungan denyut jantung diperoleh \%CVL sebelum/before usulan implementasi seluruh pekerja di Departemen Machine Shop sebesar > 30\% yaitu masuk ke dalam kategori diperlukan perbaikan metode kerja, setelah (after) usulan implementasi meski semua pekerja mengalami penurunan namun pekerja yang memiliki $<30 \%$ hanya Pekerja Bubut (1) dan Pekerja Milling-Drilling (4) yaitu masuk dalam kategori pekerja tidak terlalu mengalami kelelahan saat bekerja.

b. Hasil yang diperoleh berdasarkan aspek National Aeronautics and Space Administration Task Load (NASATLX) sebelum (before) usulan implementasi hamper seluruh pekerja di Departemen Machine Shop menerima beban kerja mental dengan nilai sebesar $>80$ yaitu masuk kedalam kategori beban kerja mental berat kecuali Pekerja Milling-Drilling (4) mempunyai skor $<80$ masuk kategori beban kerja mental sedang. Setelah (after) usulan implementasi semua pekerja memiliki skor $<80$ sehingga workload mental yang diterima masuk ke dalam kategori sedang. 
c. Berdasarkan usulan implementasi (after) yang diterapkan pada pekerja di Departemen Macbine Shop, Pekerja Bubut (1) dan Pekerja Milling-Drilling (4) yaitu perbaikan metode kerja dalam proses membubut, melubangi, dan usulan diadakannya reminder sebagai alat bantu dalam mengingat, didapatkan hasil $\%$ CVL dari kedua pekerja tersebut $<30 \%$, Tiga (3) pekerja lainnya meski mengalami penurunan masih tetap pada $>30 \%$. Hasil dari beban kerja mental yang diterima oleh seluruh pekerja di Departemen Macbine Shop mengalami penurunan setelah (after) menerapkan usulan implementasi yang diberikan. Kategori workload mental yang diterima pekerja dari yang sebelumnya masuk ke dalam kategori workload mental berat turun menjadi sedang.

\subsection{Saran}

Berdasarkan hasil analisis, direkomendasikan redesain stasiun kerja di Departemen Machine Shop yang berbasiskan Ergonomi Total dengan fokus pada task (mendesain alat kerja yang ergonomis), work organization (mengatur organisasi kerja yang ergonomis), dan environmental (melakukan redesain lingkungan fisik dan mental kerja) yang berdampak pada ENASE (Efektif, Nyaman, Aman, Sehat, dan Efisien). Sehingga pekerja sehat dan produktivitas perusahaan optimal. 


\section{DAFTAR PUSTAKA}

[1] Adiputra, N. 2002. Denyut Nadi dan Kegunaannya dalam Ergonomi. Jurnal Ergonomi Indonesia (The Indonesian Journal of Ergonomics). 1(3): 22-26.

[2] Astrand, P.O., and Rodahl, K. 1989. Textbook of Work Physiology. $2^{\text {nd }}$ ed. WB. Saunders Comp. Philadelphia. Publisher B.V., New York, USA.

[3] Christensen, P.O. 1991. Physiology of Work. Dalam: Parmeggiani, I., ed. Encyclopedia of Occuputional Healt and Safety. Third (revised) edt. ILO, Geneva: 1698-1700.

[4] Grandjean, E. 2000. Fitting the Task to The man. A Textbook of Occupational Ergonomics. London: Taylor \& Francis Ltd.

[5] Hancock dan Meshkati. 1988. Human Mental Workload. Elsevier Science

[6] Hart dan Staveland, 1981. The Workload. Jakarta. Universitas Indonesia Press.

[7] Manuaba, A. \& Vanwonterghem, K. 1996. Final Report: Improvement Quality of Life: Determination of Exposure Limits for Physical; Strenuous Tasks Under Tropical Condition. Joint Research project Indonesia-Belgium. Department of Physiology. University of Udayana Denpasar.

[8] Manuaba, A. 2006. A Total Approach In Ergonomics is A Must To Attain Human, Competitive, and Sustainable Work System and Products. Presented at Ergo Future 2006: International Symposium On Past, Present and Future Ergonomics, Occupational Safety and Health. Denpasar 28-30th August.

[9] Maretno, A., \& Haryono. 2015. Analisa Beban Kerja Fisik dan Mental dengan Menggunakan Work Sampling dan NASA-TLX untuk Menentukan Jumlah Operator. Dinamika Rekayasa Vol. 11 No. 2 Agustus 2015

[10] Rahayuningsih, S. 2014. Analisis Perbaikan Kondisi Lingkungan Kerja Terhadap Beban Kerja Mental. Jurnal Teknik Industri, Vol. 15, No. 1, Februari 2014: 80-87,

[11] Setiawan H and Rinamurti. 2019. Recommendations of Ergonomics Checkpoints and Total Ergonomics Intervention in The Pempek \& Kemplang Palembang Industry. The 1st International Conference on Research in Industrial and Systems Engineering (ICRISE), November 14 - 15, 2019 in Bali, Indonesia.

[12] Setiawan, H. 2012. Short Resting Time and Accompanying Work Music Decrease Work Fatigue and Work Stress to Workers at Crumb Rubber Factory. Proceedings International Conference 2012, Southeast Asian Network of Ergonomics Societies Conference (SEANES), Langkawi-Malaysia, July 9-12, 2012. ISBN No. 978983-41742.

[13] Setiawan, H. 2012. Technology Innovation Roadmap to Industrial Development of Rubber-Raw Material in South Sumatera (Ergonomics SHIP Approach \& Appropriate Technology Point of View). Elsevier: Procedia Economics and Finance 4 (2012). pp. 255-263.

[14] Setiawan, H. 2013. Redesain Stasiun Kerja Blanket Basah Berbasis Ergonomi Meningkatkan Produktivitas dan Kualitas Hidup Pekerja di PT. Sunan Rubber Palembang Provinsi Sumatera Selatan. Disertasi. Universitas Udayana: Program Pascasarjana. Denpasar.

[15] Setiawan, H. 2017a. Redesigning the Working System of Rubber Industries Based on Total Ergonomics and ErgoMmicMac Integration. IOP Conference Series: Journal of Physic 953. The 2nd International Joint Conference on Science and Technology (IJCST).

[16] Setiawan, H. 2017b. Rekomendasi Intervensi Ergonomi Pada UKM Unggulan Provinsi Sumatera Selatan. Jurnal Logic. Vol. 17, No. 2, Juli 2017. pp. 86-91. 